\title{
THE POTENTIAL OF WOOD AND AGRICULTURAL WASTE FOR PELLET FUEL DEVELOPMENT IN NIGERIA - A TECHNICAL REVIEW
}

\author{
Japhet J. A. \\ Department of \\ Mechanical Engineering, \\ University of Jos, Plateau \\ State, Nigeria
}

\author{
Luka B. S. \\ Department of Food Science \\ and Technology, Federal \\ University Wukari, Taraba \\ State, Nigeria
}

\author{
Maren I. B. \\ Department of \\ Mechanical Engineering, \\ University of Jos, Plateau \\ State, Nigeria
}

\author{
Datau S. G. \\ Department of \\ Mechanical Engineering, \\ University of Jos, Plateau \\ State, Nigeria
}

\begin{abstract}
Solid biomass is in common used in developing countries as fuel energy. Literature reports that about 2.9 billion people worldwide relied on solid biomass for daily cooking, and the practice is common in Africa. Woody biomass and agricultural residues account for more than $90 \%$ of total household energy consumption of some countries in Africa. In Nigeria, solid biomass is a major source of energy, and they account for about $80 \%$ of total primary energy consumed; wood-based biomass alone accounted for about $67 \%$ of the energy consumed. Due to some problems such as environmental pollution, deforestation leading erosion, etc associated with the unsustainable and unsafe method of using solid biomass energy, which is derived directly from forests of which some is converted into charcoal, the need to maximize other sources of solid biomass fuel becomes imperative. Solid biomass fuels beyond firewood and charcoal can be derived from by-products of agricultural production and forest residues. Pellets made from wood and agricultural wastes could be developed as alternative energy source. Pellets are environmentally friendly, socially accepted, economically affordable to households and has potential to develop a circular economy. This paper presents the potentials of wood and agricultural waste for pellet fuel development in Nigeria.
\end{abstract}

Keywords - Woody biomass, Agricultural Waste, Waste Management, Pellet Fuel

\section{INTRODUCTION}

Solid biomass is in common used in developing countries as fuel energy. Literature reports that nearly 2.9 billion people worldwide rely on solid biomass for their daily cooking. The practice is far more common in Africa, particularly in the sub-Saharan region. In some countries, woody biomass and agricultural residues account for more than $90 \%$ of total household energy consumption (Helbig and Roth, 2017). More than 700 million Africans (82\%) use solid biomass fuels, such as wood, charcoal, dung and agricultural residues, for their primary cooking needs. With population growth, that number is expected to reach 850-900 million by the end of the decade. This extreme usage of solid biomass fuel, in combination with households relying on unsafe and inefficient traditional cooking stoves, has constituted public health extremities (World Bank, 2014). Dependence on biomass is also associated with forest degradation and deforestation where unsustainable harvesting is practiced (Wanleys Consultancy Services 2013).

Household cooking consumes more energy than any other end-use services in low-income developing countries (IEA, 2006; Daioglou et al., 2012). Furthermore, with increasing population, resource depletion will most probably affect developing countries more extensively than developed countries. The population increase is expected to result in a greater energy demand and subsequent carbon emission rate worldwide (Das Gupta, 2014).

Solid biomass mostly is in woody form; derived directly from forests and some is converted to charcoal to serve as cooking fuel. However, there is a much larger variety of solid biomass suitable for cooking. Solid biomass fuels beyond firewood and 


\section{International Journal of Engineering Applied Sciences and Technology, 2020 Vol. 4, Issue 11, ISSN No. 2455-2143, Pages 598-607 \\ Published Online March 2020 in IJEAST (http://www.ijeast.com)}

charcoal can be derived from by-products of agricultural production and forest residues, and are becoming increasingly important (Helbig and Roth, 2017). To use these forms of biomass is to make use of these organic residues, to establish value chains, contribute to climate protection, and thus to contribute to a circular economy (Helbig and Roth, 2017). One renewable resource which can establish value chains, contribute to climate protection, and thus to contribute to a circular economy is wood pellets which are made from biomass. Biomass is the fourth largest energy source worldwide (IEA, 2014a). Wood and/or agricultural waste are compressed into pellets to produce the fuel wood pellets. Wood pellets can be used for producing electricity as well as for heating and cooking (Sikkema et al., 2011).

Solid biomass fuel is a vital component in the present and future energy supply in African countries that rely on traditional biomass as their primary cooking fuels. Reliance on biomass as the predominant source of energy for cooking is predicted to grow in the coming decades (Sander et al., 2011). These trends are due to rapid population growth which has outpaced efforts to scale up access to modern energy services in the region (IEA, 2014b). For Nigeria in particular, Solid biomass and waste are major sources of energy. They account for about $80 \%$ of total primary energy consumed in Nigeria (Ben-Iwo et al., 2016). Wood-based biomass as the main source of energy is reported at $67 \%$ in Nigeria (World Bank, 2014).

Due to some problems such as environmental pollution, deforestation leading erosion, etc associated with the unsustainable and unsafe method of using solid biomass energy: traditional (woodbased) biomass, the need to maximize other sources of solid biomass fuel becomes imperative. Solid biomass fuels beyond traditional biomass can be derived from by-products of agricultural production and forest residues. Pellets made from wood and agricultural wastes could be developed as alternative energy source. Pellets are environmentally friendly, socially accepted and economically affordable to households. This paper presents the potentials of wood and agricultural waste for pellet fuel development in Nigeria. This will establish value chains, and has potential to develop a circular economy.

\section{A. Biomass energy utilization and impact in Nigeria}

Nigeria being a major exporter of fossil fuel still relies heavily on traditional biomass for its domestic energy needs. The predominant energy for small scale cottage industries and commercial outlets and household in Nigeria, remains biomass; the use has continue to increase over the years. In Nigeria, about 95 percentage share of biomass in energy mix represents its use to meet off-grid heating, cooking needs and cottage industrial needs; such as for processing cassava, oil seeds, local bakeries, blacksmiths, brewing and other activities that are closely related to household and small scale commercial activities such as restaurants in both rural and urban areas. Similarly, some households in the urban areas have also long been dependent on biomass from rural areas for some part of their domestic fuel needs (Suleiman and Idris, 2016). Most of the biomass energy utilize for these activities in Nigeria are usually in their traditional form, without any value addition. The use of traditional biomass coupled with the use of inefficient cookstove is associated with many problems; ranging from health, economic, environmental and climate change.

The predominance of biomass in energy consumption mix can be attributed to some factors, including economic factors such as poverty and inaccessibility and high cost of modern fuels as well as socio-cultural factors, culture of individuals and the population size (Suleiman and Idris, 2016). Inspite of these challenges; biomass, wood and agricultural waste have great potential for pellet fuel development in Nigeria.

\section{B. Biomass pellet fuel}

Biomass is organic matter that can be converted into energy. Biomass commonly include: energy crops, food crops (e.g., prairie perennials or switch grass), agricultural residues (e.g., corn stover), wood waste and by-products (both mill residues and noncommercial biomass in the woods), and animal manure. Biomass materials used as fuel sources can provide heat, electrical and motive power (The Carbon Trust, 2008).

Biomass in its original form is difficult to successfully use as a fuel in large-scale applications because it is bulky, wet, and dispersed. Biomass densification (pelleting) is a technology for converting plant residues into fuel (Tumuluru et al., 2010).

Compacting biomass at a very high pressure is pelletizing - the process of producing pellets. They have significantly smaller volumes than the original biomass and a larger Volumetric Energy Density (VED) which makes them a more compact energy source, easy to transport and store (Pellet Fuel Institute, 2004).

Hence, biomass pellet fuels are a manufactured biomass fuel. They could offer interesting opportunities for development of Renewable Energy 


\section{International Journal of Engineering Applied Sciences and Technology, 2020 \\ Vol. 4, Issue 11, ISSN No. 2455-2143, Pages 598-607 \\ Published Online March 2020 in IJEAST (http://www.ijeast.com)}

in Nigeria. The market for domestic pellet application currently does not exist in Nigeria.

This solid fuel is actually mainly produced by wood residues but could also be produced by mixed biomass residues through a quite simple process of milling, drying and compacting. The main advantage of compaction is the high density of the product in comparison with the other unprocessed biomass. It also enables the production of a standardized fuel and reduction in the cost of handling, storage and transport (Hansen et al., 2009). Today, there are different pellets available from different sources and qualities; wood pellets, agropellets, torrefied pellets etc (Fig. 1).

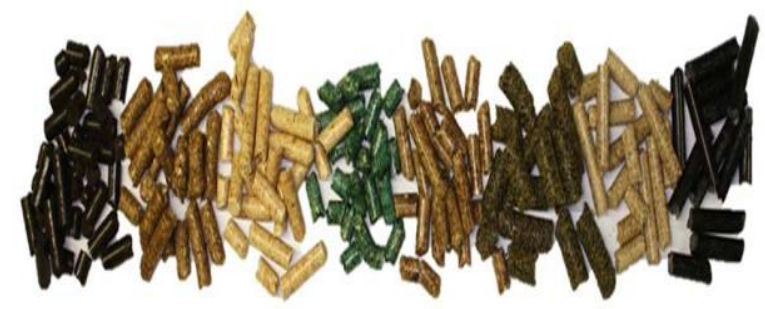

Fig. 1. Examples of pellets from different materials and processes (Source: Thrän et al., 2017)

Biomass pellet fuels, particularly wood pellets are of uniform size and shape (between 1-1/1/2 inches by approximately $1 / 4-5 / 16$ inches in diameter), making them as easy to store and use as traditional fossil heating fuels. Wood pellets also take up much less space in storage than other biomass fuels because they have a higher energy content by weight (roughly 7,750 Btu per pound at six percent moisture content) due to their densified nature and low-moisture content (typically Between 4-6 percent Moisture by weight) (Biomass Energy Resource Center, 2007).

\section{Biomass raw materials for pellet fuel}

Biomass raw materials for pellet fuels development are commonly derived from two sources - forests and agricultural residues. These have been thoroughly described by Hirsmark (2002). There are a number of biomass materials that can be used for pellet fuel development. Wood residues as saw dust, wood chips, planer shavings, recycled wood and pure wood can all be used after milling. Agricultural residues as straw, hemp or reed canary grass can be used. Short rotation coppice, e.g. Salix can also be used in pelletizing (briquetting) processes (Hirsmark, 2002). There is no data of which raw material is the most important for briquette production (Karlhager, 2008), Hirsmark (2002), showed that saw dust and planer shavings are the two most common raw materials for pellet and briquette production though. In many developing countries which produce huge quantities of agro residues, the potential agro-residues which do not pose collection and drying problems, normally associated with biomass are rice husk, groundnut shells, coffee husk and coir waste (obtained by dry process). At present, loose rice husk, groundnut shells and other agroresidues are being used mostly by small scale boilers in process industries (Grover and Mishra 1996).

\section{WOOD AND AGRICULTURAL WASTE}

\section{A. Nigerian wood waste potential}

Nigeria as a whole has a total of about 11.1 million hectares of forest and 5.5 million hectares of other wooded land (FAO, 2005). Wood waste from these huge land- masses could be explored for pellet fuel development in Nigeria.

These woods are processed in the various wood processing industries; sawmill industries, plywood mills, furniture industries, pulp and paper industries and particleboard mills (Mijinyawa et al., 2010), in the country. There are also quite a large numbers of small-scale wood processing mills in timber markets and companies manufacturing wooden products such as furniture, and many cabinet makers and carpenters all around Nigeria. Table 1 show wood waste proportion and types generated from various sources in Nigeria.

Table 1 - Wood waste proportion and types generated from various sources in Nigeria (modified from Ogunwusi, 2014)

\begin{tabular}{|l|c|l|}
\hline \multicolumn{1}{|c|}{ Source } & $\begin{array}{c}\text { Average wood } \\
\text { waste } \\
\text { generated (\%) }\end{array}$ & \multicolumn{1}{|c|}{ Type of wood waste } \\
\hline Forest & 50 & $\begin{array}{l}\text { Branches, leaves, needles, } \\
\text { stumps, roots, low grade } \\
\text { and decayed wood, } \\
\text { slashing and sawdust }\end{array}$ \\
\hline Sawmill & 43 & $\begin{array}{l}\text { Bark, sawdust, trimmings, } \\
\text { split wood, planer } \\
\text { shavings, sander dust. }\end{array}$ \\
\hline Plywood mill & 45 & $\begin{array}{l}\text { Bark, core, sawdust, } \\
\text { lillypads, veneer clippings } \\
\text { and waste, panel trim, } \\
\text { sander dust }\end{array}$ \\
\hline $\begin{array}{l}\text { Particleboard } \\
\text { mill }\end{array}$ & 5 & $\begin{array}{l}\text { Bark, screening fines, } \\
\text { panel trim, sawdust, } \\
\text { sander dust }\end{array}$ \\
\hline $\begin{array}{l}\text { Furniture } \\
\text { industry }\end{array}$ & $\begin{array}{l}\text { Planer shavings, sawdust, } \\
\text { panel trim, sander dust, } \\
\text { chips }\end{array}$ \\
\hline $\begin{array}{l}\text { Municipal \& } \\
\text { industrial } \\
\text { activities }\end{array}$ & $*$ NA & $\begin{array}{l}\text { Pruned tree branches, } \\
\text { stumps, whole trees, } \\
\text { wooden pallets, whole } \\
\text { furniture, furniture pieces }\end{array}$ \\
\hline
\end{tabular}




\section{International Journal of Engineering Applied Sciences and Technology, 2020 \\ Vol. 4, Issue 11, ISSN No. 2455-2143, Pages 598-607 \\ Published Online March 2020 in IJEAST (http://www.ijeast.com)}

*NA: Not available.

About 1.8 million tons of sawdust was estimated to be generated in Nigeria yearly (Sambo, 2009), while about 5.2 million tons of wood residues were reported to be generated (Francescato et al., 2008). Due to improper disposal methods, these huge quantities of waste are burnt in open fire, dumped in drainages or along the bank of streams and rivers, or left on any available space to rot. Fig. 2 and Fig. 3, show the activities that generate wood waste and local collection and dumping of wood waste respectively in a typical Nigerian sawmill.
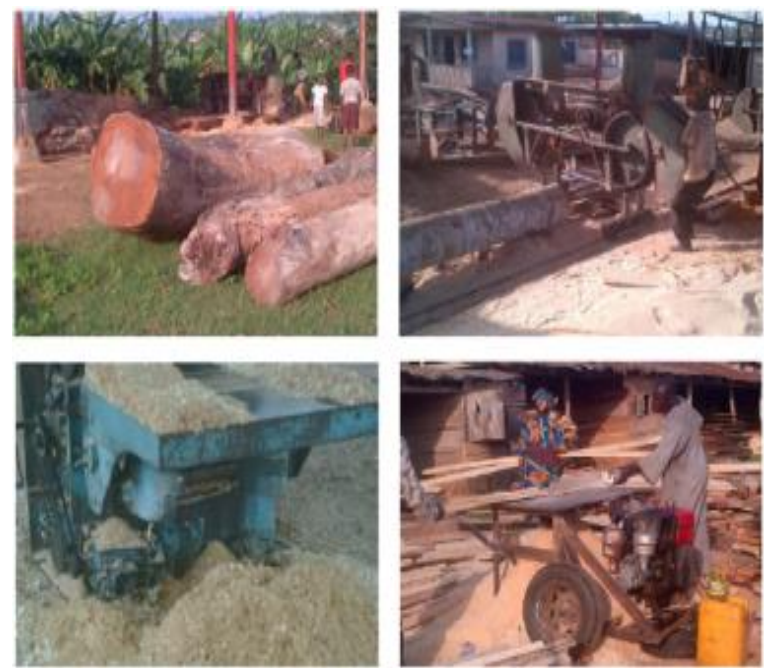

Fig. 2. Activities that generate wood waste in a typical Nigerian sawmill (Babayemi and Dauda, 2010)
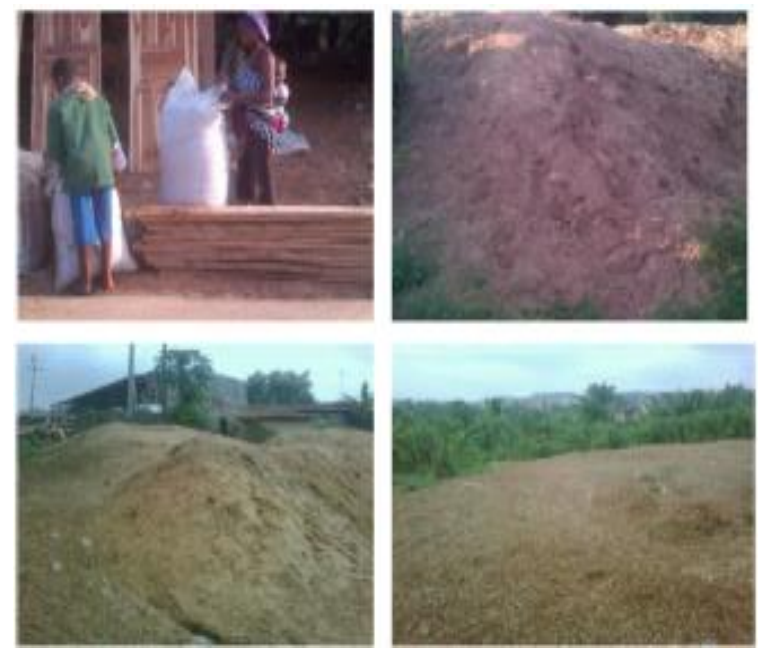

Fig. 3. Local collection and dumping of wood waste in and around a Nigerian sawmill (Babayemi and Dauda, 2010)

\section{B. Agricultural residues for cooking}

Agricultural residues are generated in large volumes every season, often being discarded as waste. Solid crop residues are the largest source of agriculture based solid biomass, comprising organic residues of straw, stems, stalks, leaves, husks, shells, peels, pits or seeds, pulp and the like from all sorts of crops. The greatest proportion is attributed to stalks of cereals (rice, wheat, maize, sorghum), cotton, and legumes (pigeon pea, bean, soya, groundnut), complemented with woody pruning's from perennial plantations like coffee, tea, cacao and fruits or nuts (mango, banana, cocoa, cashew). Agriculture based biomass is particularly relevant for communities that live close to where the biomass is produced, or for enterprises that seek to increase the performance of their business by creating a value chain based on their agricultural residues (Helbig and Roth, 2017). Fig. 4 shows the Categorization of agricultural residues that comprise solid biomass fuels for cooking.

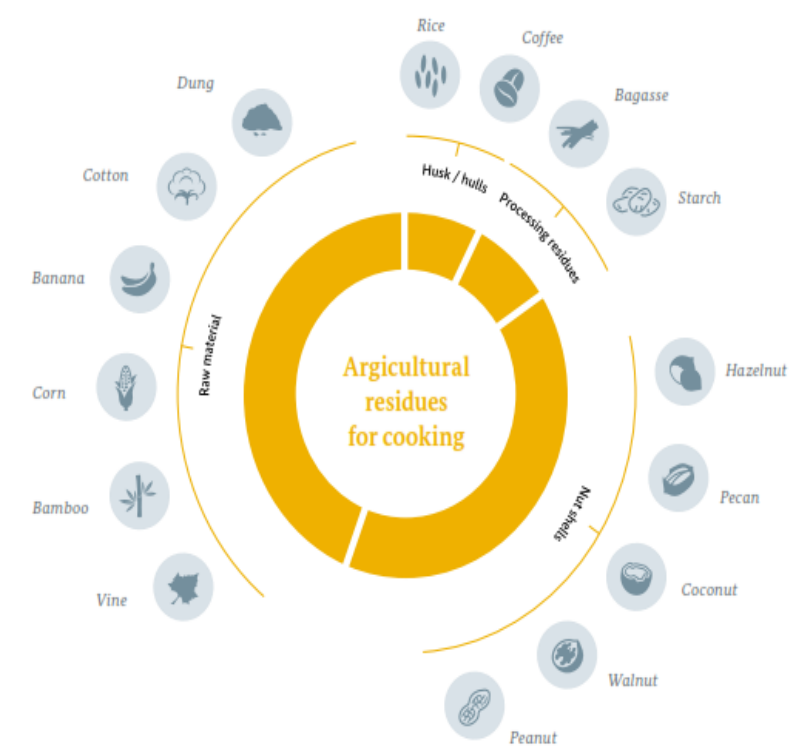

Fig. 4. Categorization of agricultural residues that comprise solid biomass fuels for cooking beyond firewood and charcoal (Helbig and Roth, 2017).

\section{Nigerian agricultural residues potential}

Agricultural residues are organic materials produced as byproduct in the course of harvesting and processing agricultural crops. They are classified into two categories: crop residues (materials left or burnt on farms after the harvest of desired crops), and agricultural industrial by-product (materials produced after crop processing). Crop residues produced during harvest are primary or field-based residues while those produced alongside the product at time of 


\section{International Journal of Engineering Applied Sciences and Technology, 2020 Vol. 4, Issue 11, ISSN No. 2455-2143, Pages 598-607 \\ Published Online March 2020 in IJEAST (http://www.ijeast.com)}

processing are secondary or process-based residues (Dutta et al., 2014).

Depending on the mode of handling, both fieldbased and process-based residues have high potential for energy production (Duku et al., 2011). Like grasses, they are underused. About $50 \%$ of the agricultural residues are burnt on cropland before the start of the next farming season (Simonyan and
Fasina, 2013). They are usually used as fodder for livestock, fertilizer for crop re-growth, for soil conservation (i.e. erosion control), or are burnt off.

Table 2 - Estimated agricultural crop residues for major crops grown in Nigeria (Simonyan and Fasina, 2013).

\begin{tabular}{|c|c|c|c|c|c|c|c|c|c|}
\hline Crop & $\begin{array}{l}\text { Productio } \\
\text { n } \\
\left(\mathrm{X} 10^{3} \mathrm{t}\right)\end{array}$ & $\begin{array}{l}\text { Residue } \\
\text { type }\end{array}$ & RPR & $\begin{array}{l}\text { Moisture } \\
\text { Content } \\
(\%)\end{array}$ & $\begin{array}{l}\text { Total } \\
\text { Residu } \\
\text { e } \\
\text { (Millio } \\
\text { n tons) }\end{array}$ & $\begin{array}{l}\text { \% } \\
\text { availabilit } \\
\mathbf{y}\end{array}$ & $\begin{array}{l}\text { Weight } \\
\text { availability } \\
\text { (Million } \\
\text { tons) }\end{array}$ & $\begin{array}{l}\text { LHV } \\
\text { (MJ/Kg } \\
\text { ) }\end{array}$ & $\begin{array}{l}\text { Residue } \\
\text { energy } \\
\text { potential } \\
(\mathbf{P J})\end{array}$ \\
\hline Rice & 3368.24 & $\begin{array}{l}\text { Straw } \\
\text { Husk }\end{array}$ & $\begin{array}{l}1.757 \\
0.2\end{array}$ & $\begin{array}{l}12.71 \\
2.37\end{array}$ & $\begin{array}{l}7.86 \\
1.19\end{array}$ & $\begin{array}{l}100 \\
100\end{array}$ & $\begin{array}{l}7.86 \\
1.19\end{array}$ & $\begin{array}{l}16.02 \\
19.33\end{array}$ & $\begin{array}{l}125.92 \\
23\end{array}$ \\
\hline Maize & 7676.85 & $\begin{array}{l}\text { Stalk } \\
\text { Cob } \\
\text { Husk }\end{array}$ & $\begin{array}{l}2 \\
0.273 \\
0.2\end{array}$ & $\begin{array}{l}15 \\
7.53 \\
11.11\end{array}$ & $\begin{array}{l}15.35 \\
2.1 \\
1.54\end{array}$ & $\begin{array}{l}70 \\
100 \\
60\end{array}$ & $\begin{array}{l}10.75 \\
2.1 \\
0.92\end{array}$ & $\begin{array}{l}19.66 \\
16.28 \\
15.56\end{array}$ & $\begin{array}{l}211.35 \\
34.19 \\
14.32\end{array}$ \\
\hline Cassava & 42533.17 & $\begin{array}{l}\text { Stalks } \\
\text { Peelings }\end{array}$ & $\begin{array}{l}2 \\
3\end{array}$ & $\begin{array}{l}15 \\
50\end{array}$ & $\begin{array}{l}85.07 \\
127.6\end{array}$ & $\begin{array}{l}20 \\
60\end{array}$ & $\begin{array}{l}17.01 \\
76.56\end{array}$ & $\begin{array}{l}17.5 \\
10.61\end{array}$ & $\begin{array}{l}297.68 \\
812.3\end{array}$ \\
\hline $\begin{array}{l}\text { Groundn } \\
\text { ut }\end{array}$ & 3799.25 & $\begin{array}{l}\text { Shells } \\
\text { Straw }\end{array}$ & $\begin{array}{l}0.477 \\
2.3\end{array}$ & 15 & $\begin{array}{l}1.81 \\
8.74\end{array}$ & 100 & $\begin{array}{l}1.81 \\
4.37\end{array}$ & $\begin{array}{l}15.66 \\
17.58\end{array}$ & $\begin{array}{l}28.35 \\
76.83\end{array}$ \\
\hline Soybean & 365.06 & $\begin{array}{l}\text { Straw } \\
\text { Pods }\end{array}$ & $\begin{array}{l}2.5 \\
1\end{array}$ & $\begin{array}{l}15 \\
15\end{array}$ & $\begin{array}{l}0.91 \\
0.37\end{array}$ & $\begin{array}{l}100 \\
100\end{array}$ & $\begin{array}{l}0.91 \\
0.37\end{array}$ & $\begin{array}{l}12.38 \\
12.38\end{array}$ & $\begin{array}{l}11.27 \\
4.58\end{array}$ \\
\hline $\begin{array}{l}\text { Sugarcan } \\
\text { e }\end{array}$ & 481.51 & $\begin{array}{l}\text { Bagasse } \\
\text { Tops/leaves }\end{array}$ & $\begin{array}{l}0.29 \\
0.3\end{array}$ & $\begin{array}{l}50 \\
10\end{array}$ & 0.14 & $\begin{array}{l}80 \\
100\end{array}$ & $\begin{array}{l}0.11 \\
0.14\end{array}$ & 18.1 & $\begin{array}{l}1.99 \\
2.21\end{array}$ \\
\hline Cotton & 602.44 & Stalk & 3.743 & 12 & 2.25 & 100 & 2.25 & 18.61 & 41.87 \\
\hline $\begin{array}{l}\text { Millet } \\
\text { Sorghum }\end{array}$ & $\begin{array}{l}5170.45 \\
7140.96\end{array}$ & $\begin{array}{l}\text { Straw } \\
\text { Straw }\end{array}$ & $\begin{array}{l}1.75 \\
1.25\end{array}$ & $\begin{array}{l}15 \\
15\end{array}$ & $\begin{array}{l}9.05 \\
8.93\end{array}$ & $\begin{array}{l}80 \\
80\end{array}$ & $\begin{array}{l}7.24 \\
7.14\end{array}$ & $\begin{array}{l}12.38 \\
12.38\end{array}$ & $\begin{array}{l}89.63 \\
88.39\end{array}$ \\
\hline $\begin{array}{l}\text { Cowpea } \\
\text { Total }\end{array}$ & 3368.24 & Shell & 2.9 & & 9.77 & 50 & $\begin{array}{l}4.89 \\
\mathbf{1 4 5 . 6 2}\end{array}$ & 19.44 & $\begin{array}{l}95.06 \\
\mathbf{1 9 5 8 . 9 4}\end{array}$ \\
\hline
\end{tabular}

RPR - Residue to product ratio; LHV - lower heating value; PJ - petajoule

Agricultural residues vary in their bulk density, moisture content, particle size and particle distribution are dependent on age of residue, stage of harvest, or physical composition and length of storage and harvesting practices (Ben-Iwo et al., 2016). Table 2 shows estimates of some major crop residues available in Nigeria. These residues have huge energy potential and can contribute greatly to pellet fuel developing in Nigeria which will establish value chains, contribute to environmental and climate protection, and thus to contribute to a circular economy.

\section{PELLET PRODUCTION WORLDWIDE AND IN NIGERIA}

Global demand for wood-based pellets is increasing dramatically, growing six-fold in the past decade (REN21 2012; REN21 2016). Currently the U.S. is the single largest wood pellet producer, producing nearly 7 million tons in 2016 (EIA 2017). Production is primarily for export to EU members; trade between the U.S. and EU quadrupled between 2011 and 2014 from 1.0 million to 4.4 million tons (REN21 2012; REN21 2016). The pellets are primarily used for large-scale heat and power generation, replacing coal as part of the EU's emission reduction goals (REN21 2016).

Since 2011, new countries have entered the market for both, pellet production (such as those from South-East Europe) and pellet consumption (such as East Asia). Also the global wood pellet trade increased. Intercontinental flows are dominated by the trade relation between the U.S. and the UK, while the non-industrial use is still mainly an intraEuropean business. Russia and the Baltic states are 
becoming increasingly important for these markets. The Asian markets show also a strong growth, with Japan and South Korea as the main consumers. Reflecting the major demand in Europe, the EU as a region is also by far the largest producer (2015: 54\%), followed by North America (2015: 35\%), which is mainly export driven. Asia, the Russian Federation, Australia and Latin America play minor roles in the global pellet production (2015: 11\%) (Thrän et al., 2017). Fig. 5 shows the countries with relevant wood pellet consumption and/or export in 2015.

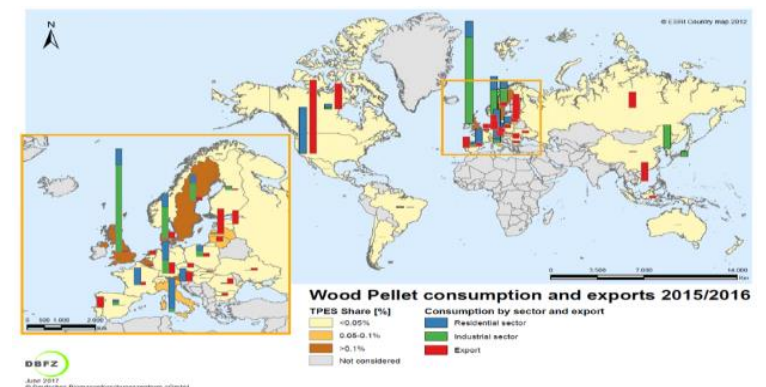

Fig. 5. Countries with relevant wood pellet consumption and/or export in 2015 (Thrän et al., 2017)

The use of pellets is insignificant in developing countries (Deepak, 2012). In Nigeria the development of pellets is still very small. However, several studies have been carried out on the use of briquette from different material as fuel in Nigeria for example, Danjuma (2013), draws an outline of techniques of briquettes production in Katsina State which can be an alternative fuel. Also, Yahaya (2012), investigated as a source of solid fuel; two sets of solid fuel briquettes were produced from rice husk using starch and gum Arabic as binders. More so, few studies have also been carried out on the use of pellet from different material as fuel in Nigeria for example, Kyauta (2015), in a work "Production and comparative study of pellets from maize cobs and groundnut shell as fuels for domestic use" handles the production and comparative study of solid fuels from agricultural waste (i.e. maize cobs and groundnut shell) that can serve as alternative energy sources for domestic use. Production and characterization of rice husk pellet was investigated as an alternative source of energy by Japhet et al. (2015). These studies rely on simple technologies such as hand-operated or locally manufactured presses to create briquettes or pellet. Their output is relatively small and was used only for the purpose of the investigation.
Though several researches have been observed from literature to have been carried out on the development of briquettes from waste material as fuel in Nigeria, there has been very little development of pellet fuels. Pellets have many advantages when compared with briquettes. When used with advanced cookstove, they burn more cleanly. They are manufactured under high pressure and denser than briquettes, with lower ash and moisture content, and can be economically transported over longer distances. However, pellet fuel is yet to be developed in Nigeria. For example, pellet production requires higher capital investment. More so, for household use, pellets require specialized stoves, these barriers may explain why there has not been development in pellet fuel production in Nigeria to date. Nevertheless, as the demands for solid fuel continue to rise, the many issues associated with the use of traditional (wood-based) biomass as the main source of energy for cooking and inefficient cookstove, pellet fuel development from wood and agricultural waste in Nigeria becomes imperative.

\section{A. Biomass pelletizing process}

Pellets are primarily manufactured from wood waste, including sawdust, shavings, and wood chips, which are byproducts of the manufacture of lumber, furniture, and other forest products. The Pellet manufacturing process consists of the following steps: receipt of raw materials, screening, grinding, drying, pelletizing, cooling, screening, and packaging. The Raw materials should be dried to the desired moisture content (Brackley and Parrent 2011; Hansen et al. 2009). Once the material is dried, it is ground so that each piece has a diameter that meets proper specifications. In Some cases, the raw material is then conditioned in a steam conditioner to soften the wood before it is compacted. This makes the raw material less abrasive to the equipment. The Next step is the pelletizing itself. Pellet Machines apply pressure to force the raw materials through holes that shape the pellets. Pressure And friction are used to increase the temperature of the wood, which in turn allows the lignum to soften and the wood fibers to be reshaped into pellets. After the pellets leave the extruder, they are air-cooled, the lignums solidify, and the pellet is formed (Roos and Brackley 2012).

The demand for pellets is increasing and other biomass wastes are been considered as raw materials. Therefore, logging residues, energy crops and its residues (for example, straw), agricultural waste, and other organic fractions of household waste could be used for pellet production (AEBIOM, 2007). However, when considering agricultural waste, it is important to note that the lignin content of wood is 
high and generally sufficient to bind wood pellets properly, but straw for example requires conditioning to achieve enough strength to provide durable pellets and minimize fines (Karwandy, 2007). Conditioning, this can be done with steam or hot water to soften the fibrous material in straw, and may require the inclusion of binder material. Usually the conditioning system is an integral part of pellet mill. The requirement of steam for conditioning purpose is approximately $4 \%$ of total amount of biomass feedstock used (Thek and Obernberger, 2004). At times binders such as starch, molasses, paraffin, or lignin sulphate are added to increase the pellet durability. Conditioned feedstock is fed into a pellet mill where rollers extrude it, forcing it to pass through die holes which effectively compress it into pellets. Adjustable knives attached to the pellet mill cut the pellets into desired length (Sultana et al., 2010).

\section{THE BENEFITS OF PELLET FUEL DEVELOPMENT IN NIGERIA}

Pellet fuel is efficient, clean and reliable. In comparison with other solid biofuels, pellets provide the following advantages and disadvantages (AEBIOM, 2007). The benefits of pellet fuel to directly relate to Nigeria have been slightly modified from AEBIOM, (AEBIOM, 2007):

\section{A. General benefits}

- Reduces Nigeria's dependence on wood fuel, charcoal and kerosene

- Sustainable source of fuel: Pellet fuel from wood and agricultural waste are a clean, environmentally friendly, natural, renewable fuel resource

- Pellet fuel cost is not dictated by world events; therefore cost is more affordable and predictable

- Reduces waste in Nigeria (as it will be made from by-products of wood and agricultural processing industry) and, therefore, diminish the cost of disposing waste.

- Provides employment opportunities for local communities in Nigeria as it is a native fuel.

- Less ash and emissions - since pellet stove emissions are so low they can be burned in most areas even those with burning restrictions

\section{B. Pellet advantages for domestic use}

- More convenient to store than any other type of wood as it doesn't degrade due to low moisture content (less than 10\%).
- High energetic value and, therefore, cost effective product: one ton of wood pellets has the heat value of more than one and a half tons of wood and stacks easily in one third the space. This makes it possible to easily store fuel for the entire season.

- Cost-efficient: high energy efficiency (due to low moisture content) which results in a reduced cost.

- Easier to handle - easiest fuel to transport and feed into burners - pellets are blown with a special pump from a truck to the storage room and are used in automatic machinery. Compared to wood or other types of wood, less volume to transport and store (due to higher energy density).

- Easier to ignite due to a consistent size and low moisture content.

- Air quality - clean, $\mathrm{CO}_{2}$-neutral pellet fuel enhances the air quality by substituting wood $\log$ burners and in this way reducing fine dust emissions. Pellets have been proven to provide the cleanest combustion of any solid fuel.

- Standard technical characteristics and low moisture content - burns predictably and provide a consistent heat output.

- Further, they have around 10\% moisture content, considerably less than the 25 to $55 \%$ typical of chips, so that less energy is wasted boiling off water.

\section{Disadvantages}

- Pelletizing process requires a certain amount of energy input and results in a higher price

- comparing to wood logs, briquettes or other forms of wood and waste fuel.

- In comparison with oil, there is a need for a larger storage facilities, regular control and removal of ashes.

\section{CONCLUSIONS}

This study highlights the potential of using wood and agricultural wastes as raw materials for the development of pellets fuels for domestic and industrial use. Large volume of agricultural wastes generated annually in Nigeria, good thermo-physical properties and ease of collection has qualified these raw materials as very good candidates for the production and development of pellet fuels. Most solid biomass comes in the form of woody biomass derived directly from forests, of which some is converted into charcoal to serve as a cooking fuel or for cottage industrial uses. However, there is a much 


\section{International Journal of Engineering Applied Sciences and Technology, 2020 Vol. 4, Issue 11, ISSN No. 2455-2143, Pages 598-607 \\ Published Online March 2020 in IJEAST (http://www.ijeast.com)}

larger variety of solid biomass suitable for cooking. These can be derived from the aforementioned byproducts of agricultural production and forest residues (stalks, pods, cobs, shells, husk, bagasse, straw, peelings and leaves).

With rising demands for solid biomass fuel, coupled with the use of inefficient cookstove, is associated with many problems; ranging from health, economic, environmental and climate change. There is a need for Nigeria to diversify its solid fuel supply by maximizing the use of biomass from wood and agricultural waste resources. Pellet fuels present an attractive substitute for biomass derived directly from stems, roots and branches of trees.

Solid biomass fuel is a vital component in the present and future energy supply in Nigeria, at present, approximately $67 \%$ of Nigerians rely on the conventional use of woody biomass as fuel, and this makes the country vulnerable to the problems associated with the use of solid biomass. The goal therefore is to reduce the high dependence on the use of traditional biomass which is derived directly from the forest by maximizing the use of biomass from wood and agricultural resources. However, this should be achieved sustainably with minimal health, environmental, climate change and socio-economic impact.

Biomass wood and agricultural wastes have higher moisture content and lower density, as a result making them technically unsuitable for direct use due to combustion and handling problems. Conversion of biomass wastes to pellets present solution for such problems; it improves biomass fuel characteristics, and reduces transportation, collection, and storage costs.

Thus, the use of biomass wood and agricultural waste for pellet fuel development in Nigeria has numerous benefits, it will establish value chains, contribute to environmental and climate protection, and will contribute to a circular economy.

\section{REFERENCES}

[1] Helbig F. and Roth C., (2017). Solid biomass fuels for cooking- beyond firewood and charcoal, Deutsche Gesellschaft fur Internationale Zusammenarbeit (GIZ) $\mathrm{GmbH}$.

[2] World Bank, (2014). Clean and Improved Cooking in Sub-Saharan Africa, A Landscape Report. Washington, DC: The World Bank Group.

[3] Wanleys Consultancy Services, (2013). Analysis of Demand and Supply of Wood Products in Kenya, Nairobi, Ministry of Environment, Water and Natural Resources: 113.
[4] IEA (International Energy Agency), (2006). World Energy Outlook 2006. Paris: IEA.

[5] Daioglou, V., van Ruijven, B. J. and van Vuuren, D. P., (2012). Model projections for household energy use in developing countries. Energy 37 (1):601-615.

[6] Das Gupta, M., (2014). Population, Poverty, and Climate Change, The World Bank Research Observer, 29(1), pp. 83-108.

[7] IEA, (2014a). Key World Energy Statistics, International Energy Agency.

[8] Sikkema, R., Steiner, M., Junginger. M., Hiegl, W., Hiegl M. T. and Faaij, A., (2011). The European wood pellet markets: current status and prospects for 2020, Biofuels, Bioproducts and Biorefining, 5(3), pp. 250-278.

[9] Sander, K., Hyseni, B. and Haider, S. W., (2011). Wood-Based Biomass Energy Development for Sub-Saharan Africa: Issues and Approaches. Working Paper No. 74545. The World Bank, Washington, DC. Available at: http://documents. worldbank.org/curated/en/2011 /09/17121432/wood-based-biomass-energydevelopment-sub-saharan-africa-issuesapproaches

[10] IEA, (2014b). Africa Energy Outlook: A Focus on Energy Prospects in Sub-Saharan Africa. World Energy Outlook Special Report. International Energy Agency, Paris. Available at: http://www.worldenergyoutlook.org/africa/

[11]Ben-Iwo J., Manovic V and Longhurst P., (2016). Biomass resources and biofuels potential for the production of transportation fuels in Nigeria, Renewable and Sustainable Energy Reviews 63(2016)172-192.

[12] Suleiman S. and Idris M. B., (2016). Biomass Consumption in Nigeria: Trends and Policy Issues, Journal of Agriculture and Sustainability, Vol. 9 (2), pp 127-157.

[13] The Carbon Trust, (2008). Biomass heating; $A$ Practical Guide for Potential Users www.carbontrust.co.uk

[14] Tumuluru J. S., Wright C. T., Kevin L. K and Hess J. R., (2010). A Review on Biomass Densification Technologies for Energy Application.

[15] Pellet Fuel Institute, (2004). Internet Address. Retrieved from http://www.pellets.heat.org/fuel/html.

[16] Hansen M. T., Jein A. R., Hayes S and Bateman P., (2009). English Handbook for Wood Pellet Combustion, National Energy Foundation, Davy Avenue, Knowlhill Milton Keynes MK5 8NG.

[17] Thrän et al., (2017). Global Wood Pellet Industry and Trade Study 2017, IEA Bioenergy Task 40. 


\section{International Journal of Engineering Applied Sciences and Technology, 2020 Vol. 4, Issue 11, ISSN No. 2455-2143, Pages 598-607 \\ Published Online March 2020 in IJEAST (http://www.ijeast.com)}

[18]Biomass Energy Resource Center, (2007). Wood Pellet Heating, A Reference on Wood Pellet Fuels \& Technology for Small Commercial \& Institutional Systems. PO Box 1611, 50 State Street, Montpelier, VT 05602 (802) 223-7770, www.biomasscenter.org

[19] Hirsmark, J., (2002). Densified Biomass Fuels in Sweden, Country report for the EU/INDEBIF project. Swedish University of Agricultural Sciences, Uppsala.

[20] Karlhager, J., (2008). The Swedish market for wood briquettes - Production and market development, Department of Forest Products, SLU, Uppsala.

[21] Grover, P. D. and Mishra, S. K., (1996). Biomass briquetting: Technology and practices, Regional Wood Energy Development Program in Asia. Field document No. 46. Bangkok, Thailand, Food and Agriculture Organization of the United Nations.

[22] Food and Agriculture Organization (FAO) of the United Nations, (2005). Global Forest Resources Assessment. http://www.fao.org/docrep/008/a0400e/a0400e00 .HTM.

[23] Mijinyawa, Y. and Bello, S. R., (2010). Assessment of Injuries in Small Scale Sawmill Industry of South Western Nigeria, Agricultural Engineering International: The CIGR Journal of Scientific Research and Development, 12: 157157.

[24] Ogunwusi, A. A., (2014). Wood Waste Generation in the Forest Industry in Nigeria and Prospects for Its Industrial Utilization, Civil and Environmental Research, 6(9): 2224-5790.

[25] Sambo, A. S., (2009.). The Place of Renewable Energy in the Nigerian Energy Sector. World Future Council.

[26] Francescato, V., Antonini, E., Bergomi, L.Z., Metschina, C., Schnedl, C., Krajnc, N., Koscik, K., Gradziuk, P., Nocentini, G. and Stranieri, S., "Wood Fuels Handbook", AIEL: Italian Agriforestry Energy Association, Legnaro, 2008.

[27] Babayemi, J. O. and Dauda, K. T., "Evaluation of Solid Waste Generation, Categories and Disposal Options in Developing Countries: A Case Study of Nigeria", Journal of Applied Sciences and Environmental Management, 13: 83-88, 2010.

[28] Dutta, K., Daverey, A. and Lin, J. G., "Evolution retrospective for alternative fuels: First to fourth generation", Renewable Energy; 69:114-22, 2014.

http://dx.doi.org/10.1016/j.renene.2014.02.044.
[29] Duku M. H.; Gu S. and Hagan E. B., “A comprehensive review of biomass resources and biofuels potential in Ghana", Renew able Sustainable Energy Rev 2011;15:404-15, 2011. http://dx.doi.org/10.1016/j.rser.2010.09.033.

[30] Simonyan, K. and Fasina O., "Biomass resources and bioenergy potentials in Nigeria", Afr J Agric 2013;8:4975-89, 2013. http://dx.doi.org/10.5897/AJAR2013.6726.

[31] REN21, "Renewables Global Status Report", 2012 Update. J. L. Sawin. Paris, REN21 Secretariat: 171, 2012.

[32]REN21, "Renewables Global Status Report", 2016 Update. J. L. Sawin. Paris, REN21 Secretariat: 271, 2016)

[33] EIA, "Monthly Densified Biomass Fuel Report." U.S. Energy Information Administration, 2017. Retrieved April 20, 2017, from http://www.eia.gov/biofuels/biomass/\#table data

[34]Deepak, A., "Reinventing the Fire - Business Models for Pellet Production as a Cooking Fuel in Developing Countries", 2012.

[35] Danjuma, M. N. Maiwada, B. and Tukur R., "Disseminating Biomass Briquetting Technology in Nigeria: A case for Briquettes Production Initiatives in Katsina State", International Journal of Emerging Technology and Advanced Engineering. Volume 3, Issue 10, 2013.

[36] Yahaya, D. B. and Ibrahim, T. G., "Development of rice husk briquettes for use as fuel", Research Journal in Engineering and Applied Sciences 1(2) 130-133, 2012.

[37] Kyauta, E. E., Adisa, A.B., Abdulkadir, L.N. and Balogun, S., "Production and Comparartive Study of Pellets from Maize Cobs and Groundnut Shell as Fuels for Domestic Use", American Journal of Engineering Research (AJER) Volume-4, Issue-1, pp-97-102, 2015.

[38] Japhet, J. A., Tokan, A., and Muhammad, M. H., "Production and characterization of rice husk pellet", American Journal of Engineering Research (AJER), Volume-4, Issue-12, pp-112119, 2015.

[39]Brackley, A.M.; Parrent, D.J., "Production of wood pellets from Alaska Grown White Spruce and Hemlock", Gen. Tech. Rep. PNW-GTR-845. Portland, OR: U.S. Department Of Agriculture, Forest Service, Pacific Northwest Research Station, 26 p, 2011.

[40]Roos, J. A. and Brackley, A. M., "The Asian Wood Pellet Markets", Gen. Tech. Rep. PNWGTR-861. Portland, OR. U.S. Department of Agriculture, Forest Service, Pacific Northwest Research Station. 25 p, 2012. 
[41]AEBIOM, "Pellets for Small-Scale Domestic Heating Systems", 2007. www.aebiom.org

[42] Karwandy, J., "Pellet production from sawmill residue: a Saskatchewan perspective", Forintek Canada Corp Report No. 2006-29, 2007.

[43] Thek, G. and Obernberger, I., "Wood pellet production costs under Austrian and in comparison to Swedish framework condition", Biomass and Bioenergy 27, 671- 693, 2004.

[44] Sultana, A., Kumar, A. and Harfield, D., "Development of agri-pellet production cost and optimum size" Bioresource Technology 101:5609-562, 2010. 